\title{
RANCANG BANGUN SISTEM INFORMASI PENGARSIPAN DATA PASIEN DI KLINIK UTAMA KASIH BUNDA PERAWANG
}

\author{
Astia Weni Syaputri, Rice Novita \\ Jurusan Sistem Informasi Fakultas Sains dan Teknologi UIN Suska Riau \\ J1. HR. Soebrantas KM.18 Panam, Pekanbaru-Riau \\ Email: Astia.wesya@gmail.com, rice.novita@uin-suska.ac.id
}

\begin{abstract}
Abstrak
Sistem informasi pengarsipan data pasien merupakan suatu sistem yang memberikan informasi laporan data pasien dan rekam medik selama perawatan dan penyimpanan seluruh data-data pasien, sehingga membantu dalam mengolah data pasien yang besar secara cepat, tepat dan efisien. Permasalahan yang terjadi dalam pengolahan data-data pasien di klinik utama kasih bunda saat ini masih bersifat konvensional, yaitu masih ditulis di buku besar sehingga membutuhkan banyak waktu dan tenaga untuk memproses data-data tersebut,selain itu data-data arsip pasien juga sering hilang karena data pasien hanya kumpulkan pada satu tempat dan tidak beraturan.Sistem informasi pengarsipan pada klinik utama kasih bunda perawang dirancang dengan teknik analisa dan perancangan metode deskriptif Object Oriented AnalysisDesign (OOAD). Sistem informasi ini dirancang menggunakan PHP dan MySQL yang dijadikan sebagai solusi untuk memecahkan masalah dalam hal pengolahan data di klinik tersebut. Sistem informasi ini mampu melakukan pengolahan data pasien rawat jalan menjadi lebih terorganisir, mempermudah cara kerja, meningkatkan efisiensi kerja, membantu dalam penyimpanan data-data, dan menghasilkan laporanlaporan yang baik untuk bagian administrasi pendaftaran, bagian administrasi tiap-tiap poli, maupun pimpinan instalasi rawat jalan klinik.
\end{abstract}

Kata Kunci : Sistem Informasi, Pengarsipan, OOAD, PHP, MySQL

\section{Pendahuluan}

Perkembangan teknologi informasi yang pesat menuntut organisasi atau institusi memiliki akses informasi yang cepat. Hampir semua kegiatan yang dilakukan membutuhkan informasi, hal tersebut mengakibatkan informasi menjadi hal yang vital dalam mendukung aktivitas administrasi maupun fungsi-fungsi dalam unit kerja lainnya. Arsip merupakan salah satu sumber informasi penting dalam menunjang kegiatan administrasi. Arsip juga berfungsi sebagai rekaman informasi, pusat ingatan, alat bantu pengambilan keputusan bahkan dapat juga sebagai bukti eksistensi sebuah organisasi. Di era teknologi saat ini kebutuhan informasi menjadi sangat penting, bahkan hampir semua organisasi maupun institusi memiliki sebuah sistem informasi. Dalam sistem informasi terdapat teknologi untuk menerima input, menjalankan model, mengakses data, menghasilkan dan mengirimkan keluaran serta membantu pengendalian sistem secara keseluruhan ( Jogiyanto, 2005).

Klinik adalah salah satu organisasi yang membutuhkan arsip pada setiap kegiatannya.Menurut pasal 1 ayat 1 peraturan mentri kesehatan tentang klinik, klinik adalah fasilitas pelayanan kesehatan yang menyelenggarakan pelayanan medis dasar dan/atau spesialistik. Dan pada pasal 14 mengatakan bahwa Setiap tenaga kesehatan yang bekerja di Klinik harus bekerja sesuai dengan standar profesi, standar prosedur operasional, standar

pelayanan, etika profesi, menghormati hak pasien, serta mengutamakan kepentingan dan keselamatan pasien. Pasal 1 Undang-undang No. 29 Tahun 2004 Tentang Praktik Kedokteran menjelaskan definisi pasien adalah setiap orang yang melakukan konsultasi masalah kesehatannya untuk memperoleh pelayanan kesehatan yang diperlukan baik secara langsung maupun tidak langsung kepada dokter atau dokter gigi. Sebagai penyedia layanan,klinik melakukan tugas-tugasnya untuk melayani pasien, dan dalam tiap pelayanannya selalu ada pencatatan-pencatatan yang nantinya akan diarsipkan.

Klinik Utama Kasih Bunda adalah salah satu klinik yang berada di Daerah Perawang, Kabupaten Siak.Klinik Utama Kasih bunda melakukan pelayanan rawat inap, rawat jalan, USG,serta KB. Dengan banyaknya pelayanan,memungkinkan banyaknya data pasien yang harus diarsipkan.Namun pengarsipan data pasien yang dilakukan di 
Klinik Utama Kasih Bunda masih menggunakan metode konvensional dengan menggunakan media kertas dan microsoft excel sebagai bahan penyimpanan.Hal tersebut akan menjadi kendala dalam pencarian data pasien yang memerlukan waktu, bahkan arsip seringkali hilang atau tidak ditemukan.Data pasien pada klinik tersebut merupakan hal yang penting untuk keberlangsungan proses bisnis pada klinik. Berdasarkan latar belakang sebelumnya dapat disimpulkan masalah yang terjadi adalah belum adanya sistem pengarsipan digital pada dalam mengelola data pasien yang berobat di Klinik Utama Kasih Bunda. Penelitian ini memiliki tujuan merancang perangkat lunak Sistem Informasi Pengarsipan

\section{Landasan Teori}

\section{A. Arsip}

Arsip berasal dari bahasa asing, orang Yunani mengatakan "Arcivum" yang artinya tempat untuk menyimpan.sering pula kata tersebut ditulis "Archeon" yang berarti Balai Kota (tempat untuk menyimpan dokumen) tentang masalah pemerintahan. Menurut bahasa Belanda yang dikatakan "Archief” mempunyai arti:

1) Tempat untuk menyimpan catatan-catatan dan bukti-bukti kegiatan yang lain.

2) Kumpulan catatan atau bukti kegiatan yang berwujud tulisan, gambar, grafik, dan sebagainya.

3) Bahan-bahan yang akan disimpan sebagai bahan pengingatan.

\section{B.Object Oriented Analysisand Design(OOAD)}

OOAD adalah metode pengembangan sistem yang lebih menekankan objek dibandingkan dengan data atau proses. Metode OOAD melakukan pendekatan terhadap masalah dari perspektif obyek, tidak pada perspektif fungsional seperti pada pemrograman terstruktur.Akhir-akhir ini penggunakan OOAD meningkat dibandingkan dengan pengunaan metode pengembangan software dengan metode tradisional. Hal tersebut untuk memenuhi peningkatan kebutuhan akan pendekatan berorientasi obyek pada aplikasi bisnis. Tahap perancangan dimulai dengan hasil keluaran yang dihasilkan tahapan analisis dan aktivitas yang dilakukan adalah secara perlahan bergeser tekanannya dari domain aplikasi atau persoalan atau masalah menuju ke domain komputasi.
Data Pasien untuk mengelola data pasien pada Klinik Utama Kasih Bunda. Perangkat lunak yang dirancang memiliki fitur penambahan data diri pasien baru, menyimpan data diri pasien, menghapus data pasien yang sudah lama tidak berobat, serta mengupdate data diri pasien, jika sewaktu mendaftar ada ketentuan yang belum terpenuhi. Studi ini menggunakan Object Oriented Analysis and Design (OOAD)untuk menganalisa dan mendisain sistem yang akan dibangun. Tools yang akan digunakan untuk OOAD adalah empat buah diagram Unified Modeling Language (UML), yaitu:use case diagram, activity diagram, sequence diagram dan class diagram.

\section{UML}

UML adalah sebuah alat bantu yang sangat handal di dunia pengembangan sistem berorientasi objek. Hal ini di sebabkan karena UML menyediakan bahasa pemodelan visual yang memungkinkan bagi pengembangan sistem untuk membuat cetak biru atas visi mereka dalam bentuk baku, mudah di mengerti serta dilengkapi dengan mekanisme efektif untuk berbagi dan mengkomunikasikan rancangan mereka yang lain (Adi Nugroho ,2005). Tujuan utama perancangan UML adalah:

a. Menyediakan bahasa pemodelan Visual yang Ekspresif dan siap pakai untuk mengembangkan dan pertukaran modelmodel yang berarti

b. Menyediakan mekanisme perluasan dan spesialisasi untuk memperluas konsep inti.

c. Mendukung spesifikasi independen bahasa pemograman dan proses pengembangan tertentu

d. Menyediakan basis formal untuk pemahaman bahasa pemodelan

e. Mendorong pertumbuhan pasar kakas berorientasi objek

f. Mendukung konsep-konsep pengembangan level lebih tinggi seperti komponen, kolaborasi, framework dan pattern.

\section{Analisa dan Perancangan}

Pada tahapini,langkahpertama yang dilakukan adalah menganalisa alur kerja sistem lama dalam pengelolaan surat masuk. Setelah itu, dilakukananalisa alur kerja sistem yang akan dibuat. Selanjutnya,dilakukan adalah perancangan sistem baru.Langkah terakhir adalah desain 
databasedan desain antar-muka dari sistem baru.Pada tahap menganalisa dan merancang sistem baru digunakan UML. Oleh sebab itu, pada tahap ini ditentukan dahulu aktor-aktor yang terlibat beserta deskripsi fungsinya, setelahitu barudibuat usecase diagram, sequence diagram, activity diagramdanclass diagram.

\section{Analisa dan Perancangan}

\section{A. Analisa alur kerja sistem lama}

Klinik Utama Kasih Bunda saat ini masih menggunakan sistem pencatatan pada buku besar. Berikut deskripsi proses bisnis yang dilakukan di Klinik Utama Kasih Bunda:

1. Pasien melakukan pendaftaran di meja administrasi dengan memberikan data identitas pasien, seperti KTP.

2. Staf administrasi mencarikan status berobat pasien yang ada di lemari pengarsipan.

3. Staf administrasi mencatat data pasien dan memberikan kartu berobat

4. Status pendaftaran pasien diberikan kepada perawat, lalu perawat memberikan status tersebut pada dokter.

5. Dokter melakukan pemeriksaan pada pasien dan mencatat diagnosa penyakit dan resep obat.

6. Resep obat dan diagnosa penyakit kemudian di serahkan kepada perawat untuk direkap dan dijadikan laporan data pasien. Kemudian di berikan kepada staf administrasi untuk di catat kembali di buku besar.

\section{B. Analisa alur kerja sistem baru}

Perancangan Sistem baru yang di usulkan adalah berbentuk sistem informasi yang digunakan untuk pengarsipan data pasien. Berikut merupakan alur sistem baru yang diusulkan.

1. Pasien datang ke klinik dengan membawa persyaratan seperti KTP ke klinik.

2. Admin menginputkan data pasien pada sistem, kemudian admin dapat mencetak kartu berobat pasien.

3. Dokter akan melihat \riwayat penyakit pasien dan memeriksa pasien, kemudian memberikan diagnosa penyakit serta resep obat.

4. Diagnosa diberikan kepada perawat, kemuadian di lakukan penginputan diagnosa pasien.

5. Laporan data pasien akan di serahkan kepada admin.

\section{Perancangan Sistem Usulan}

C.1 Penentuan Aktor yang Terlibat

Pada sistem yang dirancang ada empat aktor yang terlibat.Aktor-aktor tersebut dapat di lihat pada tabel 1.

\begin{tabular}{ll}
\hline Nama Aktor & Keterangan \\
\hline Admin & Pengguna yang \\
& mempunyai hak \\
& akses penuh terhadap \\
& sistem. \\
Dokter & Pengguna yang dapat \\
& melihat laporan arsip \\
& data pasien rawat \\
& jalan \\
Perawat & Pengguna yang dapat \\
& mengelola data \\
& diagnosa pasien \\
& rawat jalan. \\
Pimpinan & Pengguna yang dapat \\
& melihat laporan arsip \\
& data pasien rawat \\
& jalan. \\
\hline
\end{tabular}

\section{C.2 Use Case Diagram}

Gambar 1. Merupakan potongan Usecase diagram dan sistem yang dibuat. Pada usecase diagram tersebut terdapat 4 aktor yaitu admin, dokter, perawat, dan pimpinan.

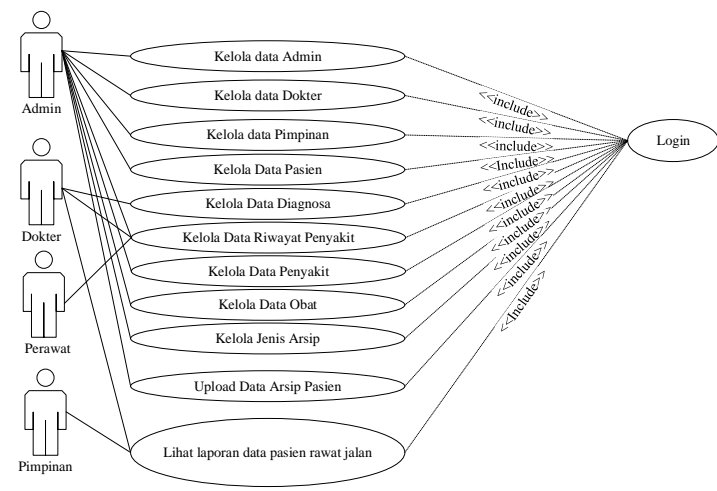

Gambar 1. Use Case Diagram 
Jurnal Ilmiah Rekayasa dan Manajemen Sistem Informasi, Vol. 5, No. 1, Februari 2019, Hal. 62-68 e-ISSN 2502-8995, p-ISSN 2460-8181

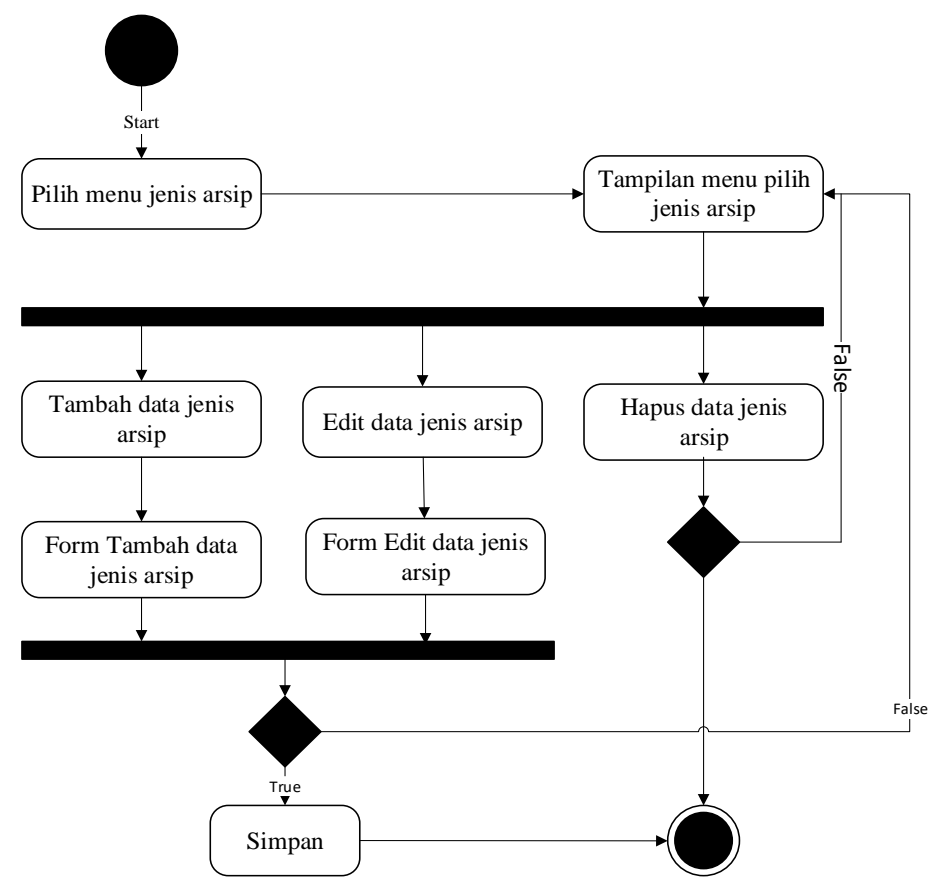

Gambar 2. Activity diagram kelola data arsip

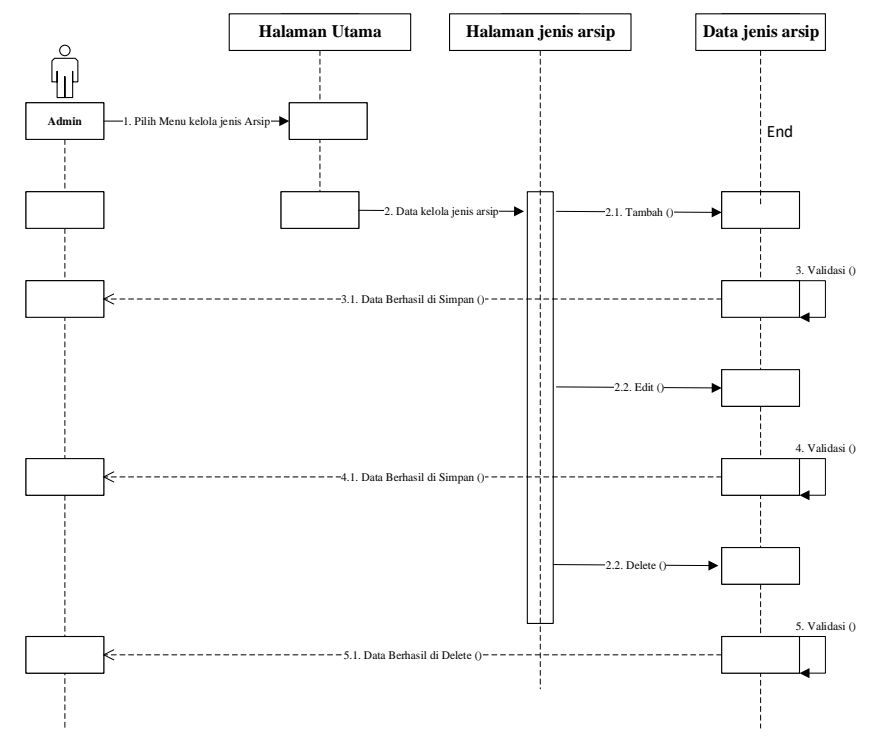

Gambar 3. Sequence diagram kelola data arsip 


\section{C3. Activity Diagram}

Pada studi ini activity diagram dibuat sebanyak usecase diagram. Gambar 2. merupakan activity diagram kelola data pengarsipan yang dilakukan oleh Klinik Utama Kasih Bunda Perawang. Pada bagian ini admin dapat melakukan 4 buah proses (menampilkan data arsip, menambah data arsip, mengedit data arsip, dan menghapus data arsip).

\section{C4. Sequence Diagram}

Pada studi ini sequence diagram dibuat sebanyak usecase diagram. Gambar 3.merupakan sequence diagram pengelolaan data arsip yang dilakukan oleh admin.

\section{C.5 Class Diagram}

Berdasarkan hasil analisis, sistem yang dibuat memerlukan sepuluh buah class. Gambar 4. merupakan potongan class diagram yang dibuat.

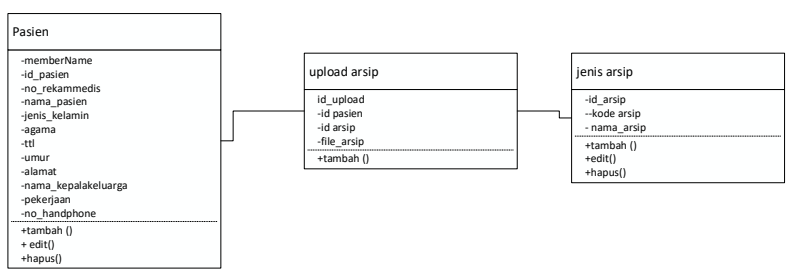

\section{C.5. perancangan Database}

Pada tabel berikut terdapat contoh perancangan database yang digunakan pada sistem pengarsipan data pasien.

\begin{tabular}{|c|c|c|c|}
\hline Nama & $\begin{array}{l}\text { Tipe } \\
\text { Data }\end{array}$ & $\begin{array}{l}\text { Panjan } \\
\text { g }\end{array}$ & $\begin{array}{l}\text { Keteranga } \\
\mathrm{n}\end{array}$ \\
\hline Id_users & Int & 11 & $\begin{array}{l}\text { Primary } \\
\text { key, auto } \\
\text { increament }\end{array}$ \\
\hline Nama & $\begin{array}{l}\text { Varcha } \\
\mathrm{r}\end{array}$ & 100 & $\begin{array}{l}\text { Nama } \\
\text { pengguna }\end{array}$ \\
\hline Tipe & $\begin{array}{l}\text { Varcha } \\
\mathrm{r}\end{array}$ & 50 & $\begin{array}{l}\text { Tipe login } \\
\text { user }\end{array}$ \\
\hline $\begin{array}{l}\text { Usernam } \\
e\end{array}$ & $\begin{array}{l}\text { Varcha } \\
\mathrm{r}\end{array}$ & 50 & $\begin{array}{l}\text { Username } \\
\text { yang } \\
\text { digunakan } \\
\text { untuk login }\end{array}$ \\
\hline Password & $\begin{array}{l}\text { Varcha } \\
\mathrm{r}\end{array}$ & 50 & Password \\
\hline
\end{tabular}

\section{IMPLEMENTASI}

Berdasarkan hasil analisa dan perancangan yang dilakukan sebelumnya, didapatkan hasil implementasi sebgai berikut.

Gambar 4. Class Diagram

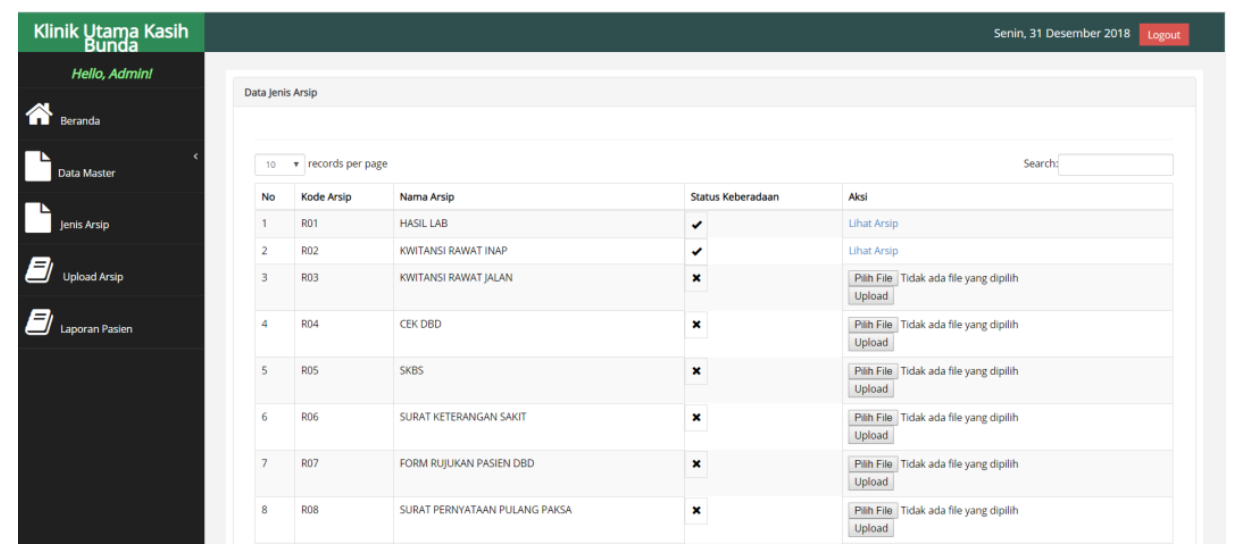

Gambar 5. Implementasi Upload Data Arsip 


\section{Penutup}

\section{A. Kesimpulan}

Berdasarkan sistem baru yang telah diimplementasikan, maka dapat diambil beberapa kesimpulan, yaitu :

1. Sistem pengarsipan data pasien dapat digunakan dalam proses pengelolaan data pasien, dan mempermudah proses administrasi pasien yang dimulai dari pendaftaran sampai dengan pengarsipan data-data pasien. Sehingga pasien tidak perlu lagi menunggu lama dalam proses administrasi.

2. Sistem informasi pengarsipan data pasien dapat memberikan informasi data-data pasien secara akurat, seperti data pasien dan data riwayat penyakit pasien, karena datadata tersebut hanya dapat di akses dan diolah oleh admin, dokter dan perawat, sehingga data-data tersebut memiliki konsistensi data.

3. Sistem informasi pengarsipan data pasien dapat memberikan laporan data pasien dengan lebih efisien dan cepat kepada pimpinan karena pada sistem terdapat fiture laporan yang dapat diakses oleh pimpinan dan dapat langsung di cetak.

4. Tampilan interface pada sistem sangat mudah di mengerti, menu-menu pada sistem tidak menyulitkan pengguna dalam menggunakan sistem tersebut, sehingga sistem termasuk user friendly.

\section{B. Saran}

Dari kesimpulan diatas, maka dapat diberikan saran yang membangun untuk kamajuan kerja praktek ini :

1. Kepada para pembaca penulis menyarankan untuk tahap selanjutnya dilakukan pengembangan (develop) dan implementasi menjadi sistem yang lebih baik dan sempurna terhadap sistem informasi pengasipan data paseien.

2. Perancangan sistem informasi pengarsipan data pasien jika diimplementasikan dapat memudahkan pekerjaan pihak rumah sakit khusunya instalasi rawat jalan dalam pengolaan data pasien agar lebih akurat dan cepat, dan laporan dapat di cetak dengan cepat karena telah menggunakan database.
Amsyah, Zulkifli. 1998. Manajemen Kearsipan. Jakarta: Gramedia Pustaka Utama. Barthos, Basir. 2005. Manajemen Kearsipan. Jakarta: Bumi Aksara.

Booch, G. James, R. Ivar, J, 2005. The Unified Modeling Language User Guide Second Edition. United State: Addison Wesley Professional.

D. W. ; Utomo and E. R. Subhiyakto, "Assessing Novice Teams in Collaborative Software Engineering Education," in Seminar Nasional Aplikasi Teknologi Informasi (SNATi), 2016.

E. M. Sibarani, "Simulating an integration systems: Hospital information system, radiology information system and picture archiving and communication system," Proceeding 2012 Int. Conf. Uncertain. Reason. Knowl. Eng. URKE 2012, pp. 62-66, 2012.

Gulo, S, Simamora, R. J, 2018. Perancangan Sistem Informasi Administrai Rawat Inap Dan Rawat Jalan Pada Rumah Sakit Umum Siti Hajar. Methomika: Jurnal Manajemen Informatika \& Komputerisasi Akuntansi. Vol. 2 No. 1

Jogiyanto. 2005. Analisis dan Desain Sistem Informasi. Penerbit Andi : Yogyakarta

Juliani,Delisa,Titiek Suliyati. ( 2013). Studi Komparatif Efektivitas Sistem Pengarsipan Manual Dengan Sistem Informasi Kearsipan Dinamis Di Badan Arsip Dan Perpustakaan Provinsi Jawa Tengah. Universitas Diponegoro Semarang. Jurnal Ilmu Perpustakaan Volume 2, Nomor 3, Tahun 2013 Halaman 1-9.

M. Berndtsson, J. Hansson, B. Olsson, and B. Lundell, Thesis Guide - A Guide for Students in Computer Science and Information Systems. 2008.

Nugroho. Adi. 2009. Rekayasa Perangkat Lunak Menggunakan UML \& Java, Andi Offset : Yogyakarta

Republik Indonesia.2010. Undang-undang No. 43 Tahun 2009 tentang Kearsipan dan Undangundang No. 43 Tahun 2007 tentang Perpustakaan. Yogyakarta: Pustaka Timur.

\section{Referensi}


Jurnal Ilmiah Rekayasa dan Manajemen Sistem Informasi, Vol. 5, No. 1, Februari 2019, Hal. 62-68 e-ISSN 2502-8995, p-ISSN 2460-8181

Sugiarto, Agus dan Teguh Wahyono. 2005.

Manajemen Kearsipan Eletronis. Gava Media:

Yogyakarta 